\title{
Felix Höflmayer
}

Deutsches Archäologisches Institut, Orient-Abteilung, Peter-Lenné-Strasse 32, 14195 Berlin, Germany. Email: fho@orient.dainst.de.

\begin{abstract}
Despite many recent attempts to settle the dispute concerning the absolute date of the Minoan Santorini eruption, there are still differences between some archaeologists and scientists on the absolute dates and the reliability of radiocarbon dating. The recent publication of over 200 new ${ }^{14} \mathrm{C}$ dates for dynastic Egypt rules out a major flaw in the historical chronology of Egypt and proves the reliability of ${ }^{14} \mathrm{C}$ dating in the Nile Valley. Therefore, the student of Aegean archaeology and eastern Mediterranean interconnections is still confronted with an archaeologically based conventional, or "low," chronology and a ${ }^{14} \mathrm{C}$-backed "high" chronology. New ${ }^{14} \mathrm{C}$ determinations from different sites of the Aegean support the high chronology for the Late Minoan (LM) IA, while recent re-evaluation of LM IB determinations are slightly higher but more or less in agreement with archaeological estimations. The present contribution reviews archaeological and scientific data for the LM IA period and argues that a reduced ( 30 to $50 \mathrm{yr})$ offset between archaeological and ${ }^{14} \mathrm{C}$ dates for the Minoan Santorini eruption may be possible, thus offering new perspectives for potential solutions for this problem.
\end{abstract}

\section{INTRODUCTION: “HIGH” AND “LOW” CHRONOLOGY AND RECENT DEVELOPMENTS}

Since the mid-1980s, a date for the Minoan eruption of Santorini 100 to $150 \mathrm{yr}$ higher than previously argued was suggested by radiocarbon dating and climatic events recorded in ice cores and tree rings from North America, Europe, and the eastern Mediterranean, placing the end of the Late Minoan (LM) IA period in the second half of the 17th century BCE (Betancourt 1987; Manning 1988, 1989a,b, 1990a,b, 1999, 2007, 2009; Michael and Betancourt 1988a,b; Friedrich et al. 1990, 2009; Manning et al. 2002, 2006, 2009; Manning and Bronk Ramsey 2003, 2009; Bronk Ramsey et al. 2004; Friedrich et al. 2006; Friedrich and Heinemeier 2009; Heinemeier et al. 2009).

On the other hand, the so-called "conventional" or "low" chronology based on archaeological synchronisms between Egypt, the Aegean, and the Levant, and ultimately founded on the historical chronology of Egypt, was defended, most notably by scholars like Peter Warren, Manfred Bietak, and Malcolm Wiener, also including the present author, placing the eruption of Santorini after the beginning of the New Kingdom in Egypt, i.e. at least after $\sim 1540$ BCE and more probably around 1500 BCE or even later (Warren 1984, 1987, 1988, 1990, 2006, 2009; Hankey 1987; Warren and Hankey 1989; Eriksson 1992; Bietak 1998; Bietak and Hein 2001; Wiener 2001, 2006a, 2009a,b; Höflmayer 2009, 2010).

In recent years, proponents of the "traditional" or "low" Aegean chronology have come under increased pressure due to new ${ }^{14} \mathrm{C}$ data from different sites of the Aegean (including Palaikastro and Aegina Kolonna; Bruins et al. 2008, 2009; Wild et al. 2010) and the results of the Oxford-based project on Egyptian chronology and ${ }^{14} \mathrm{C}$ dating (Bronk Ramsey et al. 2010; Dee et al. 2010).

To explain the difference between ${ }^{14} \mathrm{C}$ data and archaeological synchronizations, 3 possible scenarios are possible: 1) Either the archaeological synchronization between the Aegean and Egypt was flawed, so that raising of the Aegean chronology would be possible without changing dates for the Egyptian New Kingdom or questioning the ${ }^{14} \mathrm{C}$ data; 2 ) the historically derived dates for the beginning of the New Kingdom were too low and could be raised by extending reigns of certain kings, in order to keep the ${ }^{14} \mathrm{C}$ data and the long-held Aegean-Egyptian archaeological synchronization; or 3) for some (unknown) reason ${ }^{14} \mathrm{C}$ dating offers erroneous results for the Aegean early Late Bronze Age and should be dismissed as evidence for the absolute chronology.

(c) 2012 by the Arizona Board of Regents on behalf of the University of Arizona Proceedings of the 6th International Radiocarbon and Archaeology Symposium, edited by E Boaretto and N R Rebollo Franco RADIOCARBON, Vol 54, Nr 3-4, 2012, p 435-448 
In this contribution, these scenarios for fixing the date of the Minoan Santorini eruption and the late LM IA period are addressed, starting with a short review of old and new ${ }^{14} \mathrm{C}$ evidence, continuing with a critical review of archaeological arguments for a "low" or "conventional" date, and ending with a review of the Oxford model for New Kingdom Egypt and its implications for the absolute chronology of the mid-2nd millennium eastern Mediterranean.

\section{RADIOCARBON EVIDENCE FOR MINOAN SANTORINI ERUPTION AND LATE LM IA PERIOD}

Since ${ }^{14} \mathrm{C}$ evidence for the early Late Bronze Age Aegean is being disputed by some adherents of the "low" or "conventional" chronology by questioning the use of Bayesian sequencing, doubting the samples' or their contexts' reliability for the event being dated (the eruption), arguing about potential interlaboratory differences or postulating local and/or regional phenomena affecting ${ }^{14} \mathrm{C}$ data from the Aegean, it seems worthwhile to briefly review the published evidence for the late LM IA period. The main evidence comes from the settlement of Akrotiri, the famous Santorini olive branch buried in the fallout of the eruption, tsunami contexts from the coast of Crete near Palaikastro, and from the recently published sequence of Aegina Kolonna. Calibration and modeling was done with the OxCal v 4.1 program (Bronk Ramsey 2009) using the IntCal09 calibration curve (Reimer et al. 2009).

\section{Short-Lived Samples from Akrotiri (Thera)}

Short-lived samples from the volcanic destruction layer (VDL) of Akrotiri were run in a number of different laboratories, such as Oxford, Copenhagen, Heidelberg, and Vienna, providing consistent results for a point in time shortly before the Minoan eruption (late LM IA) in the second half of the 17th century BCE (Manning et al. 2006, 2009; Manning and Kromer 2011).

Assuming that all short-lived material (28 measurements published in Manning et al. 2006) reflect the same point in time (give or take a few years), maybe the last harvest stored in the settlement, the $R \_$Combine function of $\mathrm{OxCal}$ can be used to combine the short-lived samples prior to calibration, resulting in a date between 1664 and 1651 cal BC (20.1\% probability) or between 1642 and 1616 cal BC (48.1\% probability) (Figure 1$)$.

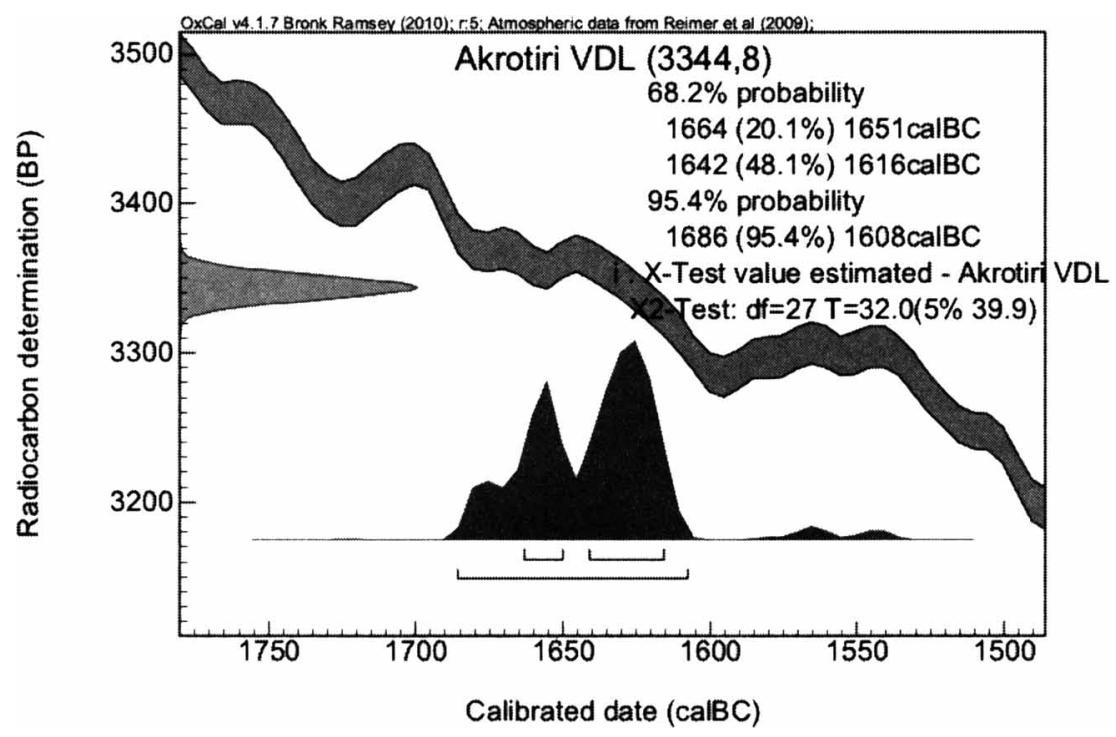

Figure 1 Calibrated age for all 28 combined short-lived samples published in Manning et al. (2006) 
However, one could also argue that the short-lived material does not represent the same point in time, but should rather be treated as a phase, being an unordered group of events, but tending to represent the latest phase of the settlement. From an archaeological point of view, such an assumption may even be more valid than treating all samples as being of (more or less) the same age. In the second model, the 28 measurements of short-lived samples are grouped as a Phase using the Tau_Boundary paired with a Boundary to define exponentially distributed events, in this case that the samples represent rather the end of the settlement (this option became available in OxCal v 4 and was not available at the time of publication of Manning et al. 2006). Four dates provided low agreement indices (OxA-1549 [A = 59.1\%], OxA-1555 [A = 50.2\%], Hd-6058-5519 [A = 36.9\%], and Hd-6059-7967 [ $\mathrm{A}=4.2 \%$ ] - two being too old (OxA-1549 and Hd-6058-5519) and two too young (OxA-1555 and Hd-6049-7967) and were removed in a second run, resulting in a date between 1632 and 1611 for the $68.2 \%$ probability range (Figure 2). This date therefore defines the last use of the settlement of Akrotiri, shortly before the Minoan eruption took place.

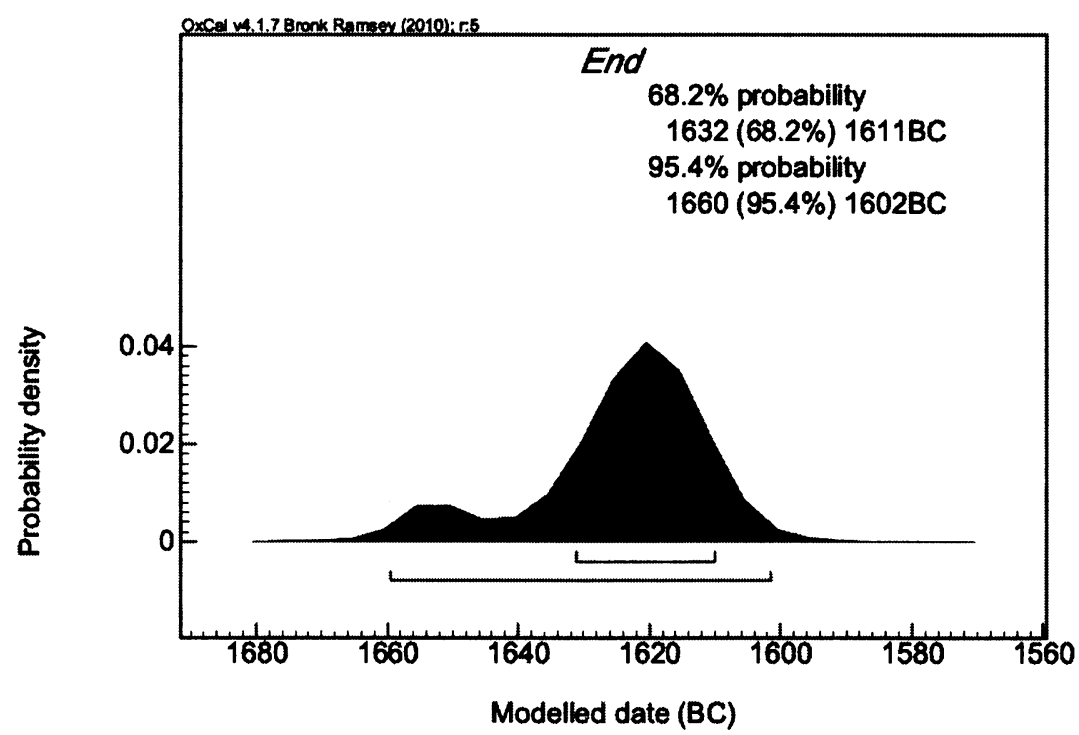

Figure 2 Modeled end of settlement based on 24 measurements of short-lived samples from Akrotiri published by Manning et al. (2006) and grouped as a Phase with a Tau_Boundary as start and a Boundary as end.

\section{Branch of an Olive Tree}

The second main indication for the Minoan Santorini eruption is the (now) famous branch of an olive tree believed to be killed by the eruption and subsequent fallout, thus being of utmost importance for dating the eruption itself (Friedrich et al. 2006, 2009; Friedrich and Heinemeier 2009; Heinemeier et al. 2009). Altogether, 72 rings (noting that identification of these is problematic in olive trees) were counted and 4 sections have been ${ }^{14} \mathrm{C}$ dated in Heidelberg $(13,24,22$, and 13 rings, respectively). A wiggle-match for these 4 dates based on the published results indicates a date between 1621 and 1605 cal BC $(1 \sigma, 68.2 \%$ probability). This date should reflect the Santorini eruption if the direct link between the last ring of the olive tree and the eruption itself is accepted (Figure 3). The high overall agreement index $\left(A_{\text {comb }}=155\right)$ shows that no fundamental errors in tree-ring counting exist and that the results of the analyzed samples are in agreement with the ${ }^{14} \mathrm{C}$ calibration curve (thus making contamination of "old" carbon via volcanic vents or similar phenom- 
ena highly unlikely). Although it might be possible that a dead branch was attached to the tree trunk for several years or even decades, the fact that a second branch found in the immediate vicinity with similar results for the last ring ( $\mathrm{J}$ Heinemeier, personal communication, April 2011), makes this assumption highly unlikely.

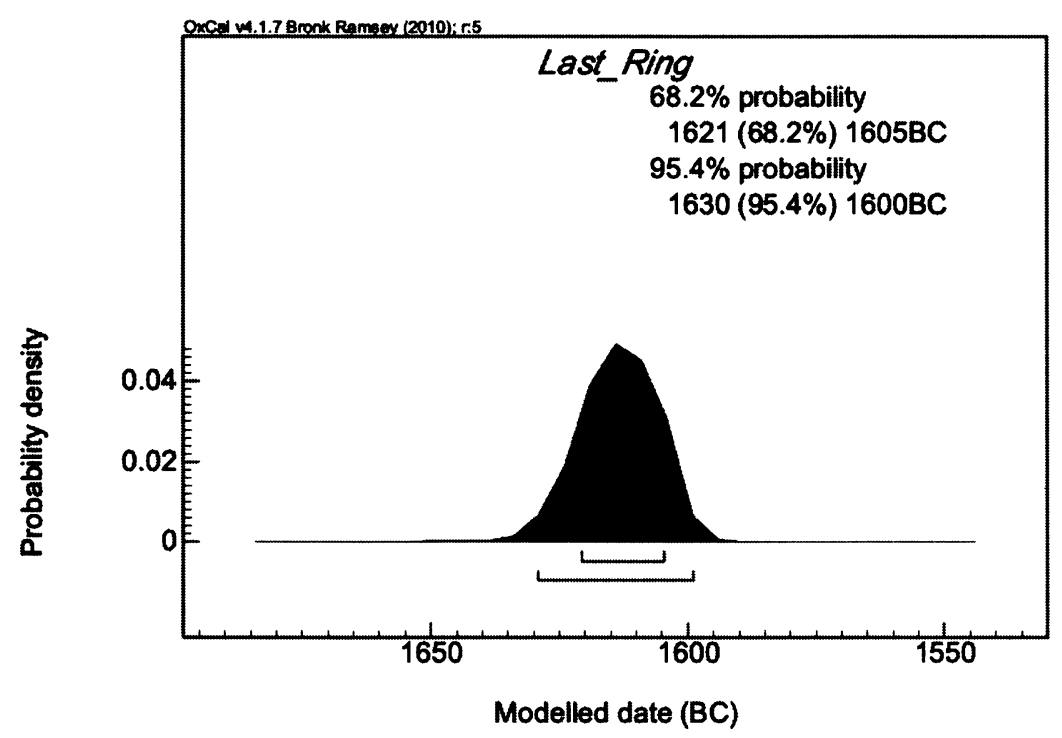

Figure 3 Modeled age for last ring of the olive branch from Santorini based on the model put forward by Friedrich et al. (2006).

\section{Sequence for Aegina Kolonna}

The recently published sequence for the site of Aegina Kolonna provides even further dating evidence for the late LM IA period (Wild et al. 2010). This site has a continuous stratigraphy from the Neolithic period to the Late Bronze Age. Thus far, more than 50 short-lived samples (mainly animal bones) were measured in Vienna, which span local phases D to M (equivalent to Early Helladic III to Late Helladic IIIA). After exclusion of some samples with possible contamination and a few outliers, this sequence contains 46 measurements. Conclusions in this contribution are based on the prior information and the model as published in Wild et al. (2010). The eruption of Santorini can be placed in phase $\mathrm{K}$, while the transition from phase $\mathrm{K}$ to phase $\mathrm{L}$ defines the transition from $\mathrm{LH}$ I to LH IIA. Based on the prior information as outlined in the publication, this transition falls between 1661 and $1591 \mathrm{BCE}$ (68.2\% probability), and is therefore in perfect agreement with the results for the short-lived samples of Akrotiri and the last ring of the olive branch (Figure 4).

\section{Palaikastro Tsunami Deposits}

Further dating evidence comes from the northeastern coast of Crete where extensive geoarchaeological tsunami deposits have been detected in the vicinity of Palaikastro. Some of these deposits contained volcanic ash, LM IA pottery, and cattle bones, which were submitted for ${ }^{14} \mathrm{C}$ dating to the Groningen laboratory. Near building 6 at Palaikastro, more animal bones were found in a large drain that also contained Santorini volcanic ash and that was linked with flooding due to the assumed tsunami. Part of a jaw (goat or sheep) and a tooth were also submitted for ${ }^{14} \mathrm{C}$ dating (Bruins et al. 2008, 2009). In both cases, it is likely that these isolated bones do not reflect the eruption proper as they were not found in primary contexts and we cannot assume that the respective animals were killed by 


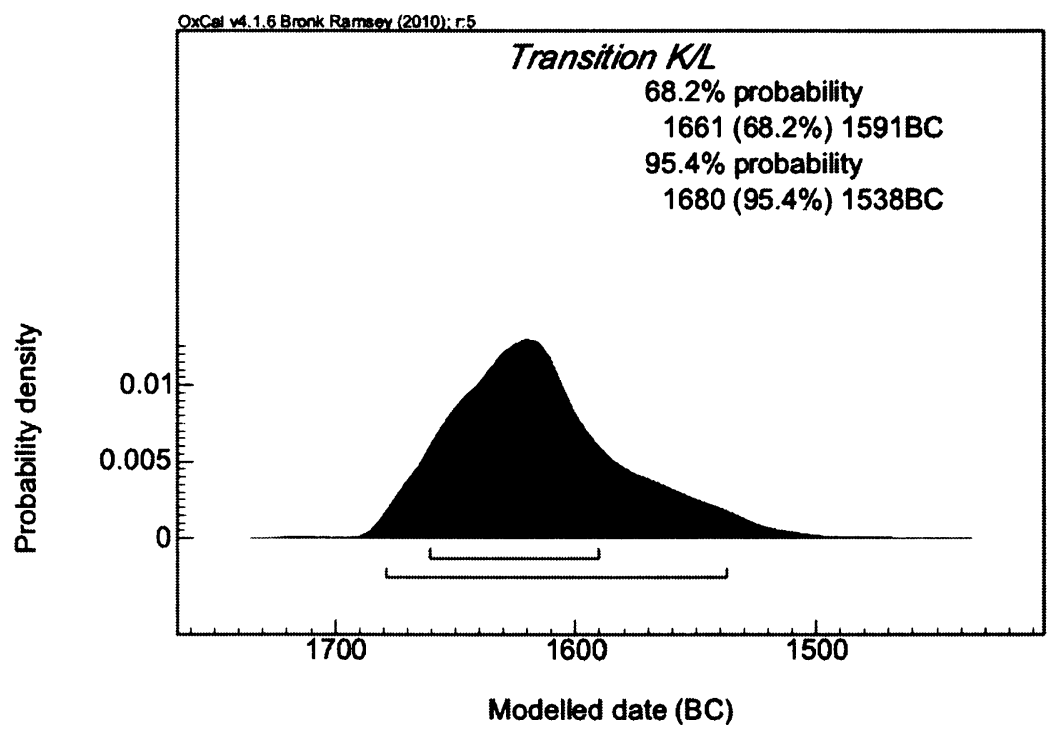

Figure 4 Modeled age for the transition from Phase $\mathrm{K}$ to Phase $\mathrm{L}$ at Aegina Kolonna based on model published by Wild et al. (2010).

the eruption and/or the tsunami effects. However, we might expect that the dates are not aberrant by hundreds of years but instead should reflect the last phase before the tsunami hit the coast. Therefore, the dates were grouped in a Phase (unordered group of events), defined by a Tau_Boundary at its start and a Boundary at its end, as it can be assumed that the bones should fall rather late than early before the tsunami. The result for this comes down to a possible date between 1657 and 1546 $\operatorname{BCE}(1 \sigma, 68.2 \%$ probability), in agreement with the data from the settlement of Akrotiri, the olive tree, and the sequence of Aegina Kolonna (Figure 5).

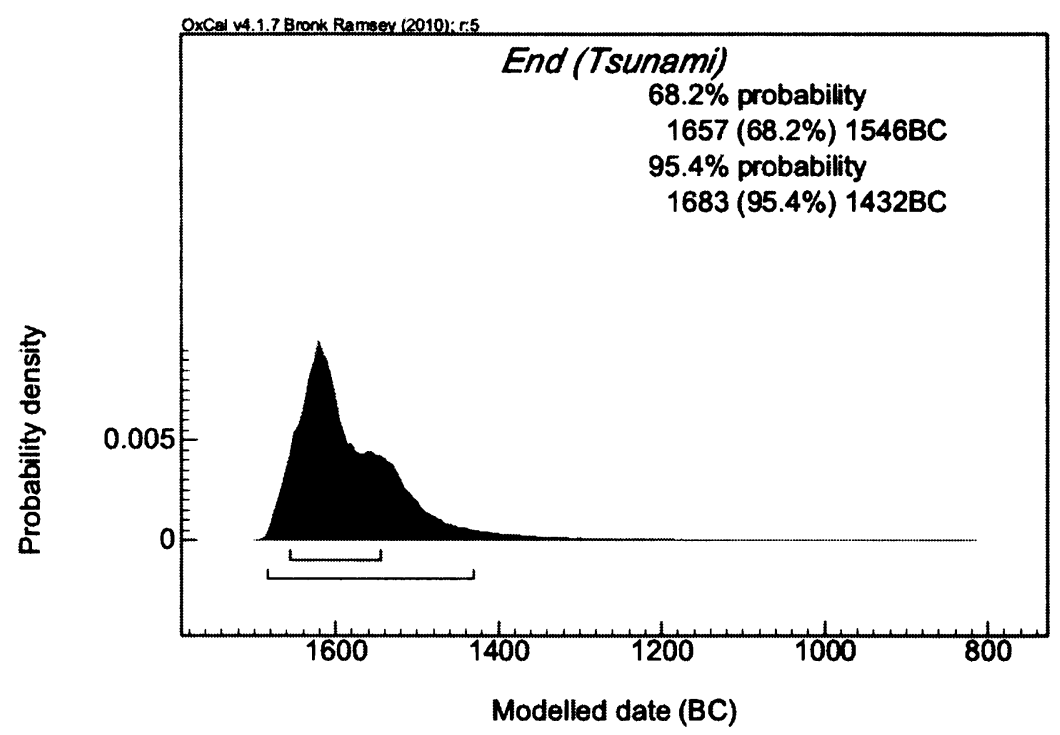

Figure 5 Modeled age for tsunami contexts based on ${ }^{14} \mathrm{C}$ determinations in Bruins et al. (2008) and grouped as a Phase defined by a Tau_Boundary as the start and a Boundary as an end. 
${ }^{14} \mathrm{C}$ evidence therefore points consistently to a date for the Minoan eruption of Santorini late in the 17 th century BCE. There is no positive evidence so far for earlier associations with acid peaks in Greenland ice cores around $1650 \mathrm{BCE}$ or a climatic event observable in European or Anatolian treering sequences $(\sim 1628$ and $\sim 1650 \mathrm{BCE})$ and in fact not even the adherents of a "high" Aegean chronology use these arguments any more. Nevertheless, since advocates of the "low" or "conventional" Aegean chronology still question these scientific results, it should be remembered that (a) all the different explanations or theories for ${ }^{14} \mathrm{C}$ data being too high (e.g. uptake of "old" volcanic $\mathrm{CO}_{2}$ in the case of short-lived samples from the settlement of Akrotiri, a dead branch or now even 2 dead branches still attached on the trunk of the olive tree, or any problems with the use of Bayesian statistics) produce (independently) exactly the same date for the eruption (or the same offset from a low-chronology point of view) and that (b) any possible explanation has to be limited in time to the late LM IA period and to the Aegean area itself. This seems unlikely. Therefore, it might be fruitful to consider the main archaeological arguments again.

\section{ARCHAEOLOGICAL ARGUMENTS FOR A “LOW” OR “CONVENTIONAL” DATE}

Advocates of the conventional Aegean chronology today base their absolute dates for the Minoan eruption of Santorini on 3 main arguments (note: a number of previous arguments and pieces of supposed evidence have been abandoned if one refers to the literature of the past decades):

- Egyptian stone vessels in Mycenaean shaft-graves;

- Pumice originating from the Thera eruption in Egypt and the Levant;

- Cypriot White Slip I pottery in the Aegean and the Levant.

While indeed the occurrence of 2 Egyptian stone vessels in shaft-graves IV and V are important for synchronizing Aegean and Egyptian chronologies, this author regards the evidence from pumice and White Slip pottery in Egypt and the Levant as inconclusive.

\section{Egyptian Stone Vessels}

An Egyptian jug from shaft-grave IV was used by Peter Warren and the present author to argue for the low chronology (Warren 2006, 2009; Höflmayer 2009). The context can be dated in the LH I period, a date that has not been challenged in the literature (Dietz 1991; Phillips 2001; Warren 2006, 2009; Höflmayer 2009). The jug itself has parallels that include the early 18th Dynasty (Lilyquist 1995), although it has to be admitted that a recent up-to-date study of Egyptian stone vessels from the Second Intermediate Period and the Egyptian New Kingdom is lacking (studies like Aston 1994; Lilyquist 1995; or Sparks 2007 do not critically review contexts and dating).

The well-known and much-discussed converted Egyptian alabastron found in shaft-grave $\mathrm{V}$ was also used by Warren and the present author to argue for a low chronology (Warren 2006, 2009; Höflmayer 2009). Again, the context was dated to the LH I period and this date has not been challenged (Dietz 1991). However, again we face similar problems in dating this vessel. Warren dated this vessel to the early 18th Dynasty or a little bit earlier, to the latest Second Intermediate Period (Warren 2006, 2009). He based this date on a comparison with drawings of stone vessels that are linked with certain kings (Lilyquist 1995). These drawings were originally published by Howard Carter (1916) regarding his work on tomb AN B in western Thebes, which he believed was the tomb of Amenhotep I (which in fact is doubtful: Polz 2007). The forms depicted in Carter's report do not represent actual vessels, as only "debris" of stone vessels was found. In fact, the depicted forms were merely believed to be represented in the fragmentary material (Carter 1916). Also, the dates offered for these forms in Lilyquist's publication are based on fragmentary material; therefore, the similarity in form between the actual vessel and the depicted forms should not be used as an argument for dating, 
and instead one should seek for existing fully preserved vessels for parallels. One remarkable parallel was found in burial 77 at the cemetery at Sawama, Middle Egypt, and was dated (on the basis of pottery) to the early 18th Dynasty (Bourriau and Millard 1971; now in Brooklyn inv.-no. 14.611). Again, the chronological conclusions are limited by the state of research in Egyptian stone vessels from the late Second Intermediate Period and early New Kingdom.

If we tentatively accept an early 18th Dynasty date for these 2 stone vessels, we have to conclude that the Minoan Santorini eruption took place after the start of the Egyptian New Kingdom and therefore-based on the historical chronology-after 1540 BCE. (If the start of the New Kingdom could be raised by a few decades, this date should also be raised accordingly.)

\section{Pumice in Egypt and the Levant}

The occurrence of pumice from the Minoan eruption of Santorini at sites in Egypt and the Levant was used to argue for an even lower date $(\sim 1500 \mathrm{BCE}$ or even later) (Bietak 2003; Wiener 2003, 2007; Bietak and Höflmayer 2007). In the framework of the SCIEM 2000 project, more than 350 samples of pumice from sites in Egypt and the Levant were analyzed by "chemical finger-printing" using neutron activation analysis (NAA) for 25 elemental concentrations (Bichler et al. 1997, 2002, 2003, 2007; Peltz et al. 1999; Bichler 2000; Peltz and Bichler 2001; Huber et al. 2003; Polinger et al. 2003; Steinhauser et al. 2006; Sterba et al. 2009). Most samples analyzed have been found in Tell el-Dabca; others come from Levantine sites including Tell el-Ajjul, Ashkelon, Megiddo and others. Up to now, no Theran pumice was found in contexts that have been dated earlier than the 18th Dynasty, and in Tell el-Dabca the first appearance of Theran pumice occurs in Str. C/2, dated to the late reign of Thutmose III and Amenhotep II (Bietak and Höflmayer 2007). It was argued that the absence of Theran pumice from earlier layers makes an eruption around $1600 \mathrm{BCE}$ or earlier highly unlikely, implying a relatively short timespan between the eruption, the collection at the shores of Egypt and the Levant, use (e.g. as an abrasive in workshops), and the disposal of pumice.

However, at least 3 important facts considerably limit the chronological value of Theran pumice in Egypt and the Levant.

1. If the pumice layer at the site of Tell el-Dabca in Str. C/2 (late reign of Thutmose III and early reign of Amenhotep II) would really reflect the time of the Minoan Santorini eruption, we have to move late LM IA as low as $\sim 1450 \mathrm{BCE}$ based on the archaeological/historical date for Str. $\mathrm{C} / 2$. Such an ultra-low estimation is not only impossible on the basis of ${ }^{14} \mathrm{C}$ dating but also on archaeological synchronization, as the LM IB period is securely linked with the earlier reign of Thutmose III with a probable transition to LM II $\sim 1450 \mathrm{BCE}$, which is also backed by recent re-evaluation of LM IB ${ }^{14} \mathrm{C}$ data (see also Höflmayer 2009; Manning 2009; Warren 2009). Therefore, the pumice layer cannot be considered as a terminus ad quem (i.e. a direct date for the Minoan eruption), but should rather be seen as a terminus ante quem (being a point in time after the Minoan eruption). The time between eruption and deposition remains unknown.

2. Recently, Malcolm Wiener argued for an eruption date of $\sim 1525$ BCE (Wiener 2006a), which was possibly reflected by ${ }^{14} \mathrm{C}$ data for the first appearance of Theran pumice in phase $\mathrm{H} 5$ in Tell el-Ajjul (Fischer 2009). Based on visual examination of the model published, the most likely date for $\mathrm{H} 5$ seems to be around $1525 \mathrm{BCE}$, although a date around $1600 \mathrm{BCE}$ is also possible. However, accepting $1525 \mathrm{BCE}$ as the first appearance of Theran pumice in Tell el-Ajjul opens a gap of at least $75 \mathrm{yr}$ between pumice layers in Tell el-Ajjul and Tell el-Dab ${ }^{\mathrm{c}}$ (earliest possible date for Str. C/2 1450 BCE or slightly later). This fact demonstrates again that the first appearance does not date the Minoan eruption but delivers merely again a terminus ante quem. If a gap of $75 \mathrm{yr}$ is possible, why should a gap of 100 or $120 \mathrm{yr}$ be impossible? Again, we simply 
do not know the time between the eruption and the deposition of pumice in archaeological contexts in Tell el-Ajjul.

3. Apart from problems in interpretation, there is also a problem of data. Although more than 350 samples of pumice have been analyzed, only a few samples come from contexts of the Second Intermediate Period. As Sterba et al. (2009) concluded: “... since the number of excavated samples from later periods greatly exceeds the number of samples from the earlier period, the pumice data are still not conclusive."

For these reasons, the only conclusion that can be drawn from the occurrence of Theran pumice in Egypt and the Levant is that the Minoan Santorini eruption must have happened earlier than the early New Kingdom. We are not able to quantify the years between eruption and disposal. The conclusion therefore has to be that pumice is not a reliable indicator for dating the Thera eruption.

\section{White Slip I Ware on Thera and in the Eastern Mediterranean}

One of the key arguments for the "low" dating of the Minoan eruption was a Cypriot White Slip I milk bowl found on Santorini. Although the vessel itself is lost today, there is no dispute about the fact that it belongs to the White Slip I series and that it comes from a pre-eruption context on Thera (Merrillees 2001). Based on the first appearance of White Slip I ware in Egypt and the Levant not before the early 18th Dynasty, Bietak and Wiener argued on various occasions that this bowl is inconsistent with the high ${ }^{14} \mathrm{C}$ data for the Minoan eruption and late LM IA (Bietak 1998, 2003; Bietak and Hein 2001; Wiener 2001, 2003, 2007, 2009a; Bietak and Höflmayer 2007).

Similar to the discussion about the chronological reliability of Theran pumice in archaeological contexts in Egypt and the Levant, this argument is based on the assumption that the first appearance of White Slip I fragments in the eastern Mediterranean provides either a terminus ad quem for the production on Cyprus or postdates the beginning of this certain ware only by a few years/decades. Bietak (2003) argued for a maximum gap of $25 \mathrm{yr}$ between production and deposition in Tell el$\mathrm{Dab}^{\mathrm{c}}$ a. However, the White Slip I bowl from Santorini shows that this ware was already produced prior to the Minoan eruption. This would open a gap of up to $\sim 100 \mathrm{yr}$ between the White Slip bowl on Thera and the first appearance in early 18th Dynasty layers in Egypt and the Levant if the high ${ }^{14} \mathrm{C}$ dates for LM IA are accepted.

There are important limitations that have to be considered regarding the chronological value of this argument. Although White Slip I pottery does not occur in Tell el-Dab ${ }^{c}$ a earlier than Str. C/3 (reign of Thutmose III), it has to be remembered that no complete vessels were found and that the published fragments only come from secondary or tertiary contexts, i.e. no material was found in situ. The first appearance of White Slip I ware in Egypt and the Levant is based on sherds, so far only from residual material. In fact, only a few fragments of White Slip I come from Str. C at Tell el$\mathrm{Dab}^{\mathrm{c}} \mathrm{a}$ : Bietak and Hein (2001) mention only 6 sherds of clear White Slip I attribution found in Str. $\mathrm{C}$ (without differentiating between $\mathrm{C} / 2$ and $\mathrm{C} / 3$ ) and Maguire (2009) mentions only a few fragments coming from Str. C (although for 2 fragments even a date in Str. D/2, dated to the late Hyksos period, has not been ruled out: DAB 378 and 383 ).

One should thus regard the first appearance of White Slip I ware in the early 18th Dynasty in the eastern Mediterranean only as a terminus ante quem for the start of the White Slip sequence on Cyprus, which should then start earlier than 1540 BCE based on the Egyptian historical chronology. An eruption date shortly before $\sim 1600 \mathrm{BCE}$ as indicated by short-lived samples from Akrotiri, 2 branches of an olive tree presumably killed by the eruption, dates from the ${ }^{14} \mathrm{C}$ sequence at Aegina Kolonna, and from the Palaikastro tsunami contexts show that in fact only a gap of a few decades 
exist between the White Slip bowl on Thera and White Slip pottery in the eastern Mediterranean, which could be explained by the fact that fragments in secondary or tertiary contexts do not represent the time of production and/or use (as also indicated by Maguire 2009).

Cypriot White Slip pottery therefore provides no convincing argument against an eruption date of $\sim 1600 \mathrm{BCE}$ or shortly before. The only reliable archaeological arguments are still the Egyptian stone vessels found in Mycenaean shaft-graves with best known parallels in the early 18th Dynasty (although a slightly earlier production cannot be ruled out).

\section{EGYPTIAN NEW KINGDOM CHRONOLOGY AND RADIOCARBON DATING}

For a long time, the discussion about the "high" and "low" chronology had to accept the text-based Egyptian historical chronology with a $\sim 1540$ BCE date for the start of the New Kingdom. Different interpretations of the complex network of regnal dates, synchronisms with the Levant, "dead reckoning," and genealogical data differed only by a few decades (Hornung 1964, 2006; Wente and van Siclen 1976; Beckerath 1994, 1997; Kitchen 2000, 2007).

Recently, the results of the extensive project on Egyptian chronology and ${ }^{14} \mathrm{C}$ dating were published, providing more than 200 new measurements for samples from securely dated contexts (Bronk Ramsey et al. 2010), including 128 dates for the New Kingdom. Separately, measurements on samples of known age were carried out, suggesting a likely reservoir effect of $-19 \pm 5{ }^{14} \mathrm{C}$ yr for the premodern Nile Valley before the Assuan Dam was built (Dee et al. 2010). For the New Kingdom, a Bayesian model was created using the known succession of kings and their regnal lengths as outlined in Shaw (2000) on the basis of Kitchen $(2000,2007)$ with an additional error of $5 \mathrm{yr}$ as prior information. Based on this model, the start for the New Kingdom can be calculated as being between 1566 and 1552 BCE (68.2\% probability) and between 1570 and 1544 BCE ( $95.4 \%$ probability) (compared to $\sim 1540 \mathrm{BCE}$ based on dead reckoning). ${ }^{14} \mathrm{C}$ data therefore backs the historical chronology in general, but tends to give slightly higher dates for the start of the New Kingdom.

It is important to stress that these dates are dependent on the prior information, especially on the king's reign lengths based on the work of Kitchen. However, the length of some reigns are disputed, especially for king Thutmose IV for whom $10 \mathrm{yr}$ are usually attributed by Kitchen (which is also used in the New Kingdom model with an additional error of $5 \mathrm{yr}$ ), whereas already in the 1970s Wente and van Siclen (1976) argued for a longer reign of $\sim 30 \mathrm{yr}$ (and also for a longer reign for Amenhotep II). They placed the beginning of the Egyptian New Kingdom at $\sim 1570$ BCE, a date even possible in the $95.4 \%$ probability range of the model based on the short Thutmose IV and Amenhotep II reigns. Furthermore, it has been argued that a longer reign might be preferable based on the significant changes in pottery forms, the high number of tomb chapels, and of officials recorded during this king's reign (Wiener 2006b; see also Manning 1999; Aston, forthcoming).

Since the model tends to place the start of the New Kingdom slightly earlier than $1540 \mathrm{BCE}$, even based on a short reign of Thutmose IV and Amenhotep II, one could consider the arguments for a longer reign of these kings. A slightly higher start for New Kingdom Egypt (by 20 yr) seems to be a possibility.

\section{CONCLUSIONS: QUANTIFYING THE “OFFSET”}

The above-mentioned arguments lead to a fresh perspective on the Thera debate. $\mathrm{New}{ }^{14} \mathrm{C}$ data from different sites in the Aegean provide consistent results for the late LM IA period and the Minoan Santorini eruption. This evidence makes it difficult to argue for site-related offsets like volcanic vents or other phenomena. The most important evidence to place the Minoan Santorini eruption in 
archaeological terms comes from Egyptian stone vessels in the Mycenaean shaft-graves, which have good parallels including the early 18th Dynasty, whereas Theran pumice in eastern Mediterranean contexts and White Slip pottery on Thera and in the Levant have been found to be inconclusive. ${ }^{14} \mathrm{C}$ data for the Egyptian New Kingdom tend to give slightly earlier results based on the reign lengths as put forward by Kitchen than expected, with a date of $1570 \mathrm{BCE}$ as the earliest possible start for the New Kingdom for the $95.4 \%$ probability range. Longer reigns of Thutmose IV and Amenhotep II (also argued for by pottery specialists) as already put forward by Wente and van Siclen (1976), might even raise the ${ }^{14} \mathrm{C}$-backed start of the New Kingdom a little bit further.

All this indicates that we do not deal with an offset of more than $100 \mathrm{yr}$ between the archaeological date (after the start of the New Kingdom) and the scientific date (shortly before 1600 BCE) for the Minoan eruption of Santorini. The "offset" comes down to $\sim 50 \mathrm{yr}$ or even less, if a slightly higher date for the Egyptian New Kingdom is accepted. Given the unsatisfactory state of research in the field of Egyptian stone vessels of the Second Intermediate Period and the early New Kingdom, it does not seem impossible that the 2 Egyptian stone vessels from the Mycenaean shaft-graves could have been produced 1 or 2 generations earlier than previously suggested (i.e. in the late Second Intermediate Period). A new critical re-evaluation of the development of Egyptian stone vessels from the Second Intermediate Period to the New Kingdom might be desirable in order to check a possible earlier dating of these crucial synchronisms.

\section{ACKNOWLEDGMENTS}

I would like to thank David Aston, Irene Forstner-Müller, Jan Heinemeier, Alexander MacGillivray, and especially Sturt Manning for fruitful discussions, for reading earlier drafts of this paper, and for correcting my English.

\section{REFERENCES}

Aston BG. 1994. Ancient Egyptian Stone Vessels: Materials and Forms (Studien zur Archäologie und Geschichte Altägyptens 5). Heidelberg: Heidelberger Orientverl.

Aston DA. Forthcoming. Radiocarbon and the reigns of Thutmosis III and Ramesses II. Ägypten \& Levante.

Beckerath J. 1994. Chronolgie des ägyptischen Neuen Reiches (Hildesheimer ägyptologische Beiträge 39). Hildesheim: Gerstenberg.

Beckerath J. 1997. Chronologie des pharaonischen Ägypten: Die Zeitbestimmung der ägyptischen Geschichte von der Vorzeit bis 332 v. Chr (Münchener ägyptologische Studien 46). Mainz am Rhein: Philipp von Zabern.

Betancourt PP. 1987. Dating the Aegean Late Bronze Age with radiocarbon. Archaeometry 29(1):45-9.

Bichler M. 2000. Thera ashes. Datum lines: stratigraphy of the emissions of the Santorini volcano in the Eastern Mediterranean (Relative Chronology IV). In: Bietak M, editor. The Synchronisation of Civilisations in the Eastern Mediterranean in the Second Millennium B.C. Proceedings of an International Symposium at Schloß Haindorf, 15th - 17th of November 1996 and at the Austrian Academy, Vienna, 11th - 12th of May 1998. Vienna: Verlag der Österreichischen Akademie der Wissenschaften. p 30-1.
Bichler M, Egger H, Preisinger A, Ritter D, Stastny P. 1997. NAA of the "Minoan pumice" at Thera and comparison to alluvial pumice deposits in the Eastern Mediterranean region. Journal of Radioanalytical and Nuclear Chemistry 224(1-2):7-14.

Bichler M, Peltz C, Saminger S, Exler M. 2002. Aegean tephra: an analytical approach to a controversy about chronology. Agypten \& Levante 12:55-70.

Bichler M, Exler M, Peltz C, Saminger S. 2003. Thera ashes. In: Bietak M, editor. The Synchronisation of Civilisations in the Eastern Mediterranean in the Second Millennium B.C. II. Proceedings of the SCIEM 2000 - EuroConference Haindorf 2nd - 7th of May 2001. Vienna: Verlag der Österreichischen Akademie der Wissenschaften. p 11-21.

Bichler M, Duma B, Huber H, Musilek A. 2007. Distinction of pre-Minoan pumice from Santorini, Greece. In: Bietak M, Czerny E, editors. The Synchronisation of Civilisations in the Eastern Mediterranean in the Second Millennium B.C. III. Proceedings of the SCIEM 2000 - 2nd EuroConference, Vienna 28th of May - 1st of June 2003. Vienna: Verlag der Österreichischen Akademie der Wissenschaften. p 49-58.

Bietak M. 1998. The Late Cypriot White Slip I-Ware as an obstacle to the high Aegean chronology. In: Balmuth MS, Tykot RH, editors. Sardinian and Aegean 
Chronology. Towards the Resolution of Relative and Absolute Dating in the Mediterranean. Proceedings of the international colloquium "Sardinian Stratigraphy and Mediterranean Chronology." Tufts University, 17-19 March 1995. Oxford: Oxbow. p 321-2.

Bietak M. 2003. Science versus archaeology: problems and consequences of High Aegean chronology. In: Bietak M, editor. The Synchronisation of Civilisations in the Eastern Mediterranean in the Second Millennium B.C. II. Proceedings of the SCIEM 2000 - EuroConference Haindorf 2nd - 7th of May 2001. Vienna: Verlag der Österreichischen Akademie der Wissenschaften. p 23-33.

Bietak M, Hein I. 2001. The context of White Slip wares in the stratigraphy of Tell el-Dab'a and some conclusions on Aegean Chronology. In: Karageorghis V, editor. The White Slip Ware of Late Bronze Age Cyprus. Proceedings of an International Conference Organized by the Anastasios G. Leventis Foundation, Nicosia in Honour of Malcolm Wiener. Nicosia, 29-30 October 1998. Vienna: Verlag der Österreichischen Akademie der Wissenschaften. p 171-94.

Bietak M, Höflmayer F. 2007. Introduction: high and low chronology. In: Bietak M, Czerny E, editors. The Synchronisation of Civilisations in the Eastern Mediterranean in the Second Millennium B.C. III. Proceedings of the SCIEM 2000 - 2nd EuroConference, Vienna 28th of May - 1st of June 2003. Vienna: Verlag der Österreichischen Akademie der Wissenschaften. p 13-23.

Bourriau J, Millard A. 1971. The excavation of Sawâma in 1914 by G. A. Wainwright and T. Whittemore. Journal of Egyptian Archaeology 57:28-57.

Bronk Ramsey C, Manning SW, Galimberti M. 2004. Dating the volcanic eruption at Thera. Radiocarbon 46(1):325-44.

Bronk Ramsey C. 2009. Bayesian analysis of radiocarbon dates. Radiocarbon 51(1):337-60.

Bronk Ramsey C, Dee MW, Rowland JM, Higham TFG, Harris SA, Brock F, Quiles A, Wild EM, Marcus ES, Shortland AJ. 2010. Radiocarbon-based chronology for dynastic Egypt. Science 328(5985):1554-7.

Bruins HJ, MacGillivray A, Synolakis CE, Benjamini C, Keller J, Kisch HJ, Klügel A, van der Plicht J. 2008. Geoarchaeological tsunami deposits at Palaikastro (Crete) and the Late Minoan IA eruption of Santorini. Journal of Archaeological Science 35(1):191-212.

Bruins HJ, van der Plicht J, MacGillivray JA. 2009. The Minoan Santorini eruption and tsunami deposits in Palaikastro (Crete): dating by geology, archaeology, ${ }^{14} \mathrm{C}$, and Egyptian chronology. Radiocarbon 51(2): 397-411.

Carter H. 1916. Report on the tomb of Zeser-Ka-Ra Amenhetep I, discovered by the Earl of Carnarvon in 1914. Journal of Egyptian Archaeology 3:147-54.

Dee MW, Brock F, Harris SA, Bronk Ramsey C, Shortland AJ, Higham TFG, Rowland JM. 2010. Investigating the likelihood of a reservoir offset in the radiocar- bon record for ancient Egypt. Journal of Archaeological Science 37(4):687-93.

Dietz S. 1991. The Argolid at the Transition to the Mycenaean Age: Studies in the Chronology and Cultural Development in the Shaft Grave Period. Copenhagen: National Museum of Denmark.

Eriksson KO. 1992. Late Cypriot I and Thera. Relative chronology in the Eastern Mediterranean. In: Åström P, editor. Acta Cypria. Acts of an International Congress of Cypriote Archaeology held in Göteborg on 22-24 August 1991. Part 3. Jonsered: Paul Åströms Förlag. p 152-223.

Fischer PM. 2009. The chronology of Tell el-Ajjul, Gaza: stratigraphy, Thera, pumice and radiocarbon dating. In: Warburton DA, editor. Time's Up! Dating the Minoan Eruption of Santorini. Acts of the Minoan Eruption Chronology Workshop, Sandbjerg, November 2007. Aarhus: Aarhus University Press. p 253-65.

Friedrich WL, Heinemeier J. 2009. The Minoan eruption of Santorini radiocarbon dated to $1613 \pm 13 \mathrm{BC}-$ geological and stratigraphic considerations. In: Warburton DA, editor. Time's Up! Dating the Minoan Eruption of Santorini. Acts of the Minoan Eruption Chronology Workshop, Sandbjerg, November 2007. Aarhus: Aarhus University Press. p 56-63.

Friedrich WL, Wagner P, Tauber H. 1990. Radiocarbon dated plant remains from the Akrotiri excavation on Santorini, Greece. In: Hardy DA, Renfrew C, editors. Thera and the Aegean World III. Proceedings of the Third International Congress. Santorini, Greece 3-9 September 1989. London: The Thera Foundation. p 188-96.

Friedrich WL, Kromer B, Friedrich M, Heinemeier J, Pfeiffer T, Talamo S. 2006. Santorini eruption radiocarbon dated to 1627-1600 B.C. Science 312(5773):548.

Friedrich WL, Kromer B, Friedrich M, Heinemeier J, Pfeiffer T, Talamo S. 2009. Santorini eruption radiocarbon dated to $1627-1600 \mathrm{BC}$ : further discussion. In: Manning SW, Bruce MJ, editors. Tree-Rings, Kings, and Old World Archaeology and Environment. Oxford: Oxbow Books. p 293-8.

Hankey V. 1987. The chronology of the Aegean Late Bronze Age. In: Åström P, editor. High, Middle or Low? Acts of an International Colloquium on Absolute Chronology Held at the University of Gothenburg 20th - 22nd August 1987. Gothenburg: Paul Åströms Förlag. p 39-59.

Heinemeier J, Friedrich WL, Kromer B, Bronk Ramsey C. 2009. The Minoan eruption of Santorini radiocarbon dated by an olive tree buried by the eruption. In: Warburton DA, editor. Time's Up! Dating the Minoan Eruption of Santorini. Acts of the Minoan Eruption Chronology Workshop, Sandbjerg, November 2007. Aarhus: Aarhus University Press. p 285-93.

Höflmayer F. 2009. Aegean-Egyptian synchronisms and radiocarbon chronology. In: Warburton DA, editor. Time's Up! Dating the Minoan Eruption of Santorini. Acts of the Minoan Eruption Chronology Workshop, 
Sandbjerg, November 2007. Aarhus: Aarhus University Press. p 187-95.

Höflmayer F. 2010. Die Synchronisierung der minoischen Alt- und Neupalastzeit mit der ägyptischen Chronologie [PhD dissertation]. Vienna.

Hornung E. 1964. Untersuchungen zur Chronologie und Geschichte des Neuen Reiches (Ägyptologische Abhandlungen 11).

Hornung E. 2006. The New Kingdom. In: Hornung E, Krauss R, Warburton D, editors. Ancient Egyptian Chronology. Biggleswade: Brill. p 197-217.

Huber H, Bichler M, Musilek A. 2003. Identification of pumice and volcanic ash from archaeological sites in the Eastern Mediterranean region. Agypten \& Levante 13:83-105.

Kitchen KA. 2000. The historical chronology of ancient Egypt, a current assessment. In: Bietak M, editor. The Synchronisation of Civilisations in the Eastern Mediterranean in the Second Millennium B.C. Proceedings of an International Symposium at Schloß Haindorf, 15th - 17th of November 1996 and at the Austrian Academy, Vienna, 11th - 12th of May 1998. Vienna: Verlag der Österreichischen Akademie der Wissenschaften. p 39-52.

Kitchen KA. 2007. Egyptian and related chronologies. Look, no sciences, no pots! In: Bietak M, Czerny E, editors. The Synchronisation of Civilisations in the Eastern Mediterranean in the Second Millennium B.C. III. Proceedings of the SCIEM 2000 - 2nd EuroConference, Vienna 28th of May - 1st of June 2003. Vienna: Verlag der Österreichischen Akademie der Wissenschaften. p 163-71.

Lilyquist C. 1995. Egyptian Stone Vessels: Khian through Tuthmosis IV. New York: Metropolitan Museum of Art.

Maguire LC. 2009. Tell el-Dab'a XXI: The Cypriot Pottery and its Circulation in the Levant (Untersuchungen der Zweigstelle Kairo des Österreichischen Archäologischen Institutes 33). Vienna: Verlag der Österreichischen Akademie der Wissenschaften.

Manning SW. 1988. The Bronze Age eruption of Thera: absolute dating, Aegean chronology and Mediterranean cultural interrelations. Journal of Mediterranean Archaeology 1:17-82.

Manning SW. 1989a. A new age for Minoan Crete. New Scientist (11 February):60-3.

Manning SW. 1989b. The Santorini eruption: an update. Journal of Mediterranean Archaeology 2:303-13.

Manning SW. 1990a. The eruption of Thera: date and implications. In: Hardy DA, Renfrew C. Thera and the Aegean World III. Proceedings of the Third International Congress. Santorini, Greece 3-9 September 1989. London: The Thera Foundation. p 29-40.

Manning SW. 1990b. The Thera eruption: the Third Congress and the problem of the date. Archaeometry 32(1):91-100.

Manning SW. 1999. A Test of Time: The Volcano of Thera and the Chronology and History of the Aegean and
East Mediterranean in the Mid Second Millennium $B C$. Oxford: Oxbow.

Manning SW. 2007. Clarifying the 'high' v. 'low' Aegean/Cypriot chronology for the mid second millennium BC: assessing the evidence, interpretive frameworks, and current state of the debate. In: Bietak M, Czerny E, editors. The Synchronisation of Civilisations in the Eastern Mediterranean in the Second Millennium B.C. III. Proceedings of the SCIEM 2000 2nd EuroConference, Vienna 28th of May - 1st of June 2003. Vienna: Verlag der Österreichischen Akademie der Wissenschaften. p 101-37.

Manning SW. 2009. Beyond the Santorini eruption: some notes on dating the Late Minoan IB period on Crete, and implications for Cretan-Egyptian relations in the 15 th century BC (and especially LM II). In: Warburton DA, editor. Time's Up! Dating the Minoan Eruption of Santorini. Acts of the Minoan Eruption Chronology Workshop, Sandbjerg, November 2007. Aarhus: Aarhus University Press. p 207-26.

Manning SW, Bronk Ramsey C. 2003. A Late Minoan III absolute chronology for the Aegean - combining archaeology with radiocarbon. In: Bietak $\mathrm{M}$, editor. The Synchronisation of Civilisations in the Eastern Mediterranean in the Second Millennium B.C. II. Proceedings of the SCIEM 2000 - EuroConference Haindorf 2nd - 7th of May 2001. Vienna: Verlag der Österreichischen Akademie der Wissenschaften. p 111-33.

Manning SW, Bronk Ramsey C. 2009. The dating of the earlier Late Minoan IA period: a brief note. In: Warburton DA, editor. Time's Up! Dating the Minoan Eruption of Santorini. Acts of the Minoan Eruption Chronology Workshop, Sandbjerg, November 2007. Aarhus: Aarhus University Press. p 227-45.

Manning SW, Kromer B. 2011. Radiocarbon dating archaeological samples in the Eastern Mediterranean, 1730 to 1480 : further exploring the atmospheric radiocarbon calibration record and the archaeological implications. Archaeometry 53(2):413-39.

Manning SW, Bronk Ramsey C, Doumas C, Marketou T, Cadogan G Pearson CL. 2002. New evidence for an early date for the Aegean Late Bronze Age and Thera eruption. Antiquity 76(293):733-44.

Manning SW, Bronk Ramsey C, Kutschera W, Higham TFG, Kromer B, Steier P, Wild EM. 2006. Chronology for the Aegean Late Bronze Age 1700-1400 B.C. Science 312(5773):565-9.

Manning SW, Bronk Ramsey C, Kutschera W, Higham TFG, Kromer B, Steier P, Wild EM. 2009. Dating the Santorini/Thera eruption by radiocarbon: further discussion (AD 2006-2007). In: Manning SW, Bruce MJ, editors. Tree-Rings, Kings, and Old World Archaeology and Environment. Papers Presented in Honor of Peter Ian Kuniholm. Oxford: Oxbow Books. p 299316.

Merrillees RS. 2001. Some Cypriote White Slip pottery from the Aegean. In: Karageorghis V, editor. The White Slip Ware of Late Bronze Age Cyprus. Proceed- 
ings of an International Conference Organized by the Anastasios G. Leventis Foundation, Nicosia in Honour of Malcolm Wiener. Nicosia, 29-30 October 1998. Vienna: Verlag der Österreichischen Akademie der Wissenschaften. p 89-100.

Michael HN, Betancourt PP. 1988a. The Thera eruption: continuing discussion of the dating. II. Further arguments for an early date. Archaeometry 30(1):169-70.

Michael HN, Betancourt PP. 1988b. The Thera eruption: continuing discussion of the dating. IV. Addendum. Archaeometry 30(1):180-1.

Peltz C, Bichler M. 2001. Classification of archaeologically stratified pumice by INAA. Journal of Radioanalytical and Nuclear Chemistry 248:81-7.

Peltz C, Schmid P, Bichler M. 1999. INAA of Aegean pumices for the classification of archaeological findings. Journal of Radioanalytical and Nuclear Chemistry 242:361-77.

Phillips JS. 2001. Stone vessel production: new beginnings and new vision in New Palace Crete. In: Shortland AJ, editor. The Social Context of Technological Change. Egypt and the Near East, 1650 - 1550 BC. Proceedings of a Conference Held at St. Edmund Hall, Oxford 12-14 September 2000. Oxford: Oxbow Books. p 73-91.

Polinger Foster K, Bichler M. 2003. Theran pumice from Egyptian graves. In: Polinger Foster K, Laffineur R, editors. Metron. Measuring the Aegean Bronze Age. Proceedings of the 9th International Aegean Conference New Haven, Yale University, 18-21 April 2002. Liège. p 431-9.

Polz D. 2007. Der Beginn des Neuen Reiches: Zur Vorgeschichte einer Zeitenwende (Deutsches Archäologisches Institut Kairo Sonderschrift 31). Berlin: Walter de Gruyter.

Reimer PJ, Baillie MGL, Bard E, Bayliss A, Beck JW, Blackwell PG, Bronk Ramsey C, Buck CE, Burr GS, Edwards RL, Friedrich M, Grootes PM, Guilderson TP, Hajdas I, Heaton TJ, Hogg AG, Hughen KA, Kaiser KF, Kromer B, McCormac FG, Manning SW, Reimer RW, Richards DA, Southon JR, Talamo S, Turney CSM, van der Plicht J, Weyhenmeyer CE. 2009. IntCal09 and Marine09 radiocarbon age calibration curves, 0-50,000 years cal BP. Radiocarbon 51(4): 1111-50.

Shaw I, editor. 2000. The Oxford History of Ancient Egypt. Oxford: Oxford University Press.

Sparks RT. 2007. Stone Vessels in the Levant. The Palestine Exploration Fund Annual 8. Leeds: Maney.

Steinhauser G, Sterba JH, Bichler M, Huber H. 2006. Neutron activation analysis of Mediterranean volcanic rocks - an analytical database for archaeological stratigraphy. Applied Geochemistry 21(8):1362-75.

Sterba JH, Polinger Foster K, Steinhauser G, Bichler M. 2009. New light on old pumice: the origins of Mediterranean volcanic material from ancient Egypt. Journal of Archaeological Science 36(8):1738-44.
Warren PM. 1984. Absolute dating of the Bronze Age eruption of Thera (Santorini). Nature 308(5959):4923.

Warren PM. 1987. Absolute dating of the Aegean Late Bronze Age. Archaeometry 29(2):205-11.

Warren PM. 1988. The Thera eruption: continuing discussion of the dating. III. Further arguments against an early date. Archaeometry 30(1):176-9.

Warren PM. 1990. Summary of the evidence for the absolute chronology of the early part of the Aegean Late Bronze Age. In: Hardy DA, Renfrew C, editors. Thera and the Aegean World III. Proceedings of the Third International Congress. Santorini, Greece 3-9 September 1989. London: The Thera Foundation. p 24-6.

Warren PM. 2006. The date of the Thera eruption in relation to Aegean-Egyptian interconnections and the Egyptian historical chronology. In: Czerny E, Hein I, Hunger H, Melman D, Schwab A, editors. Timelines. Studies in Honour of Manfred Bietak. Leuven: Peeters. p 305-21.

Warren PM. 2009. The date of the Late Bronze Age eruption of Santorini. In: Warburton DA, editor. Time's Up! Dating the Minoan Eruption of Santorini. Acts of the Minoan Eruption Chronology Workshop, Sandbjerg, November 2007. Aarhus: Aarhus University Press. p 181-6.

Warren P, Hankey V. 1989. Aegean Bronze Age Chronology. Bristol: Bristol Classical Press.

Wente EF, van Siclen CC. 1976. A chronology of the New Kingdom. In: Wente EF, Johnson JH, editors. Studies in Honor of George R. Hughes. Chicago: University of Chicago Press. p 217-61.

Wiener MH. 2001. The White Slip I of Tell el-Dab'a and Thera: critical challenge for the Aegean Long chronology. In: Karageorghis V, editor. The White Slip Ware of Late Bronze Age Cyprus. Proceedings of an International Conference Organized by the Anastasios $G$. Leventis Foundation, Nicosia in Honour of Malcolm Wiener. Nicosia, 29-30 October 1998. Vienna: Verlag der Österreichischen Akademie der Wissenschaften. p 195-202.

Wiener MH. 2003. Time out: the current impasse in Bronze Age archaeological dating. In: Polinger Foster $\mathrm{K}$, Laffineur R, editors. Metron. Measuring the Aegean Bronze Age. Proceedings of the 9th International Aegean Conference New Haven, Yale University, 1821 April 2002. Liège. p 363-99.

Wiener MH. 2006a. Chronology going forward (with a query about 1525/4 B.C.). In: Czerny E, Hein I, Hunger H, Melman D, Schwab A, editors. Timelines. Studies in Honour of Manfred Bietak. Leuven: Peeters. p 317-28.

Wiener MH. 2006b. Egypt \& time. Ägypten \& Levante 16:285-99.

Wiener MH. 2007. Times change: the current state of the debate in Old World chronology. In: Bietak M, Czerny $\mathrm{E}$, editors. The Synchronisation of Civilisations in the 
Eastern Mediterranean in the Second Millennium B.C. III. Proceedings of the SCIEM 2000 - 2nd EuroConference, Vienna 28th of May - 1st of June 2003. Vienna: Verlag der Österreichischen Akademie der Wissenschaften. p 25-47.

Wiener MH. 2009a. Cold fusion: the uneasy alliance of history and science. In: Manning SW, Bruce MJ, editors. Tree-Rings, Kings, and Old World Archaeology and Environment. Papers Presented in Honor of Peter Ian Kuniholm. Oxford: Oxbow Books. p 277-92.

Wiener MH. 2009b. The state of debate about the date of the Theran eruption. In: Warburton DA, editor. Time's Up! Dating the Minoan Eruption of Santorini. Acts of the Minoan Eruption Chronology Workshop, Sandbjerg, November 2007. Aarhus: Aarhus University Press. p 197-206.

Wild EM, Gauß W, Fortenpointner G, Lindblom M, Smetana R, Steier P, Thanheiser U, Weninger F. $2010 .{ }^{14} \mathrm{C}$ dating of the Early to Late Bronze Age stratigraphic sequence of Aegina Kolonna, Greece. Nuclear Instruments and Methods in Physics Research B 268(7-8): 1013-21. 